\title{
What matters in audit pricing - industry specialization or overall market leadership?
}

\author{
Andrew C. Ferguson ${ }^{a}$, Jere R. Francis ${ }^{b, c}$, Donald J. Stokes ${ }^{\text {d,e }}$ \\ ${ }^{a}$ School of Accounting, University of New South Wales, ${ }^{b}$ University of Missouri- \\ Columbia, and ${ }^{c}$ Department of Accounting and Business Information Systems, University \\ of Melbourne, ${ }^{d}$ School of Accounting, University of Technology, Sydney, and ${ }^{e}$ Capital \\ Markets CRC Ltd, Australia.
}

\begin{abstract}
Ferguson, Francis and Stokes (2003) report that audit industry fee premia primarily reside with joint national and city-specific industry leadership as opposed to merely firm-wide (national) industry expertise, suggesting auditor choice among the Big 5 is best conceptualized on joint industry specialization in city-specific markets and nationally. This study examines whether the prior results could be confounded by the presence of city-specific overall market leadership effects. Our findings reaffirm that joint local and national auditor industry expertise is valued by audit clients. Further, overall city-specific leadership, by itself, also matters in fee determination and results in higher fees, though at a slightly weaker level of statistical significance.
\end{abstract}

Key words: Audit markets; Audit fees; Industry specialization; Market leadership; Big 5 accounting firms

JEL classification: M42 


\subsection{Introduction}

Prior economics of auditing literature has documented the existence of fee premiums paid to Big 8/6/5 industry specialists, in addition to premiums attributable to the generic brand name of the Big 8/6/5. Such studies include Palmrose 1986, Craswell, Francis and Talyor (1995); DeFond Francis and Wong (2000); Ferguson and Stokes 2002, and Ferguson, Francis and Stokes (2003) [hereafter FFS]. The most recent of these studies, FFS, finds evidence for the existence of joint national and city-specific industry leader premiums. In investigating aspects of city-specific industry leadership, FFS develop the city-level line of inquiry first suggested by Francis, Stokes and Anderson (1999) [hereafter FSA].

This study continues the city-level line of inquiry. Since FFS focus solely on joint industry leadership effects, we investigate the possibility that their results might be sensitive to different characterizations of 'leadership' consistent with FSA's alternative conceptualizations. FSA characterize city-level leadership two ways: either (a) city-level market leadership, or (b) city-level industry leadership and pose the following questions:

'Do city-level market leaders command the same kind of fee premiums that have been found using national data? Is there a premium for city-level industry leaders? ${ }^{1}$

The second question is addressed by FFS, who document the strength of premiums for joint city-specific and national industry leaders vis-à-vis purely national effects. In this study, we test if the results reported by FFS (that industry expertise is the

\footnotetext{
${ }^{1}$ FSA. p. 187.
} 
joint result of both national and city-specific leadership) could in fact be driven by overall city leadership (a proxy for overall city reputations). In other words, is the "city" component of the joint national/city leadership that we document in Model 3 Table 3 in FFS confounded by overall city leadership (a proxy for overall city reputations)? ${ }^{2}$

This question is interesting considering descriptive statistics on the overlap between city-specific industry leadership and overall city market leadership. For the full sample of Big 5 firm audited clients in 1998 in the FFS sample, and described further in Table 1 below, 24\% are audited by the overall city leader (CITYLEAD), whilst 36\% of observations are audited by the city-specific industry leader (INDLEAD). Interestingly $35 \%$ of the audits by city-specific industry leaders reported in FFS are undertaken by an auditor who is both the city-specific industry leader and the overall city market leader (or combined leaders (COMBLEAD)). The pattern of overlap between the two leadership characterizations is shown in Table 1 and is consistent across cities, with a range from $22.7 \%$ to $54.7 \%$, and averages $35.2 \%$ for the full sample. This suggests the reported joint national and city-specific industry specialist premiums in FFS could be confounded by overall city-specific market leadership.

[Insert Table 1 here]

\subsection{Theoretical background and hypothesis}

There are a number of reasons why auditors could seek to hold positions of market leadership. Extant research documents a positive association between market

\footnotetext{
${ }^{2}$ Note that we reproduce Model 3 from Table 3 in FFS in Table 2 of this paper for ease of comparison.
} 
share and profitability. Syzmanski, Bharadwaj and Varadarajan (1993) perform a metaanalysis on forty-eight studies investigating the market share and profitability relationship. They find that on average, market share has a positive effect on profitability. A related stream of research supports the notion that early entrants in new markets often achieve a first-mover advantage which results in dominant market shares and a sustainable competitive advantage through the creation of entry barriers (Kerin, Varadarajan and Peterson (1992); Szymanski (1995)). ${ }^{3}$

Second, there are also a number of studies which point to supply side signaling benefits of high market share. Market leadership signals product quality, which enables market leaders to charge higher prices. Higher prices in turn provide a further signal of product quality (Scitovsky 1945). Shapiro (1983a) demonstrates analytically that higher prices for high quality experience goods are a mechanism to ensure the high quality of such goods by making it costly to shirk on quality. Shapiro (1983b) further demonstrates that higher prices for these goods represent normal returns to reputation (quality) investments.

We suggest consumers use market share data to make inferences about product quality. For example, Smallwood and Conlisk (1979) and Caminal and Vines (1996) demonstrate analytically that market share provides a positive signal of product quality when quality is uncertain. Hellofs and Jacobson (1999) report survey and experimental evidence that market share is positively associated with perceived product quality for "premium" brands and for products where "exclusivity" is not a concern. ${ }^{4}$

\footnotetext{
${ }^{3}$ Frank and Cook (1995) argue more generally that many markets have become winner-take-all lotteries. In such markets, there are economic rents to be gained by firms that achieve market dominance.

${ }^{4}$ Premium brands refer to products having higher prices, and exclusivity is associated with status goods whose distribution must be restricted to retain their aura of exclusivity. The audits provided by Big 5
} 
Thus the marketing literature documents the ability of suppliers who hold large market shares to generate positive reputation effects and perceived value amongst buyers. Large city-level market share is also likely to be valued in audit markets. For example, the city-level analysis conducted in FSA using US data to analyze the 1989 audit firm mergers indicates that the merger between Ernst \& Whinney and Arthur Young forming Ernst \& Young was:

'More of a leadership merger, in which the primary effect was to significantly increase market share in cities in which the pre-merger firms already operated, resulting in a substantial increase in market leadership (cities with top ranking). ${ }^{5}$

The implication was that Ernst \& Young strategically increased the number of city-specific overall market leadership positions, and that such positions provided perceived product quality signaling and/or profitability benefits.

On the demand side, if product signaling benefits apply in audit markets, the client would regard a city-specific market leader as possessing those attributes the client associates with high quality audits. Demand for overall city-specific market leaders would arise from perceptions that these suppliers offered a superior product, consistent with FSA's assertion that:

accounting firms are accurately characterized by these two conditions. Product quality is uncertain in auditing, and Craswell and Francis (1999) characterize audits as experience goods whose quality can only be assessed through experience (Nelson 1970; Wilde 1981).

${ }^{5}$ FSA. p. 187 
'Market share is important because it measures leadership from which inferences can be made about auditor reputations and expertise. ${ }^{6}$

In summary, supply side benefits of overall city market leadership are based around both profitability and product signaling benefits. On the demand side, buyers perceive that city market leaders can provide superior product quality. This study seeks to establish whether the previously reported premiums for joint national and city-specific industry leadership might be impacted by the presence of buyers of audit services who are willing to pay higher prices for overall city-specific leadership.

\subsection{Empirical tests}

\subsection{Sample selection}

We utilize the same data set as FFS, which comprises the full sample of Australian listed companies in 1998. It is noted that consistent with FFS, companies with non-fiscal year ends (i.e., firms having a reporting period greater than or less than 12 months) and companies having head office domiciles offshore are excluded from the sample.

\footnotetext{
${ }^{6}$ FSA. p. 186
} 


\subsection{Measurement of variables}

The model used is a logical extension of that used in FFS, testing for joint national and local industry leadership as well as overall city leadership effects. We specify the OLS regression model as follows:

$$
\begin{aligned}
& \text { LAF }=b_{0}+b_{1} \text { LTA }+b_{2} \text { LSUB }+b_{3} \text { CATA }+b_{4} \text { QUICK }+b_{5} \text { DE }+b_{6} \text { ROI + } \\
& b_{7} \text { FOREIGN }+b_{8} \text { OPINION }+b_{9} \text { YE }+b_{10} \text { LOSS }+b_{11} \text { NATIND + } b_{12} \text { NATOVER + } \\
& b_{13} \text { NATALONE + b14 INDNOTNAT + b15 OVERNOTNAT + e }
\end{aligned}
$$

\begin{tabular}{|c|c|}
\hline LAF & $=$ natural log of audit fees, \\
\hline LTA & $=$ natural log of total assets, \\
\hline LSUB & $=$ natural $\log$ of the number of subsidiaries, \\
\hline CATA & $=$ ratio of current assets to total assets, \\
\hline QUICK & $=$ ratio of current assets (less inventories) to current liabilities, \\
\hline DE & $=$ ratio of long-term debt to total assets, \\
\hline ROI & $=$ ratio of earnings before interest and tax to total assets, \\
\hline FOREIGN & $=$ proportion of subsidiaries that represent foreign operations, \\
\hline OPINION & $=$ indicator variable, 1 = qualified audit report, \\
\hline YE & $=$ indicator variable, 1 = non-June $30^{\text {th }}$ year end, \\
\hline LOSS & $=$ indicator variable, $1=$ loss in any of the past three years, \\
\hline
\end{tabular}

where:

Test Variables

NATIND = indicator variable, $1=$ national industry \#1 or \#2 and city-specific industry leader (but not overall city leader),

NATOVER = indicator variable, $1=$ national industry \#1 or \#2 and overall city leader (but not city-specific industry leader),

NATALONE =indicator variable, $1=$ national industry \#1 or \#2 (but not either city-specific industry leader or overall city leader),

INDNOTNAT =indicator variable, $1=$ city-specific industry leader alone (but not overall city leader and not national industry \#1 or \#2)

OVERNOTNAT =indicator variable, $1=$ =verall city leader alone (but not city industry leader and not national industry \#1 or \#2)

e $=$ error term assumed to have normal OLS regression properties. 
The first ten control variables are the standard audit fee control variables and are discussed in further detail in FFS pages 438-9. The first test variable, NATIND ( $\mathrm{n}=115)$ picks up the joint effect of national industry leadership (\#1 or \#2) and the city-specific industry leader who is not an overall city leader. This variable thus removes the potential confounding effects of overall city-specific leadership from the FFS Model 3 test variable. ${ }^{7}$ The second test variable, NATOVER $(n=23)$ tests the joint effect of national industry leadership (\#1 or \#2) and the overall city leader who is not a city-specific industry leader. This test variable controls for joint national and overall city-specific market leadership after excluding potentially confounding city-specific industry leadership effects. If joint national industry and local market leadership matters, we would observe a significant positive co-efficient on this indicator, after controlling for other effects. NATALONE ( $\mathrm{n}=163)$ is the third test variable which seeks to isolate the impact of purely national industry leadership excluding city-specific industry leaders and overall city leaders. The fourth test variable INDNOTNAT $(n=45)$ tests for fee premiums for the city-specific industry leader who is not the overall city leader or a national industry leader. This variable picks up pure city-specific industry leadership after removing any national industry leadership and any local market leadership impact. Last, OVERNOTNAT $(\mathrm{n}=53)$, indicates overall city leaders alone who are not city-specific industry leaders or national industry leaders. This indicator variable identifies the impact of pure local market leaders excluding national industry and local industry effects. If

\footnotetext{
${ }^{7}$ The model specification is similar to FFS, and we focus on outright leadership at the local level owing to the insignificance of second ranked industry leaders in Model 2 of Table 3 in FFS. In addition, Panel A of Table 1 in FFS (p. 435) documents a sizeable market share 'gap' of 12 percentage points or greater for 4 out of 5 cities. This indicates that the focus of this study on the overall city \#1 is not likely to be impaired by overall \#2 competitors who are 'close' to the leader in terms of market share.
} 
overall city-level market leadership matters, irrespective of joint national industry effects, we would expect a positive and significant co-efficient on this indicator variable.

\subsection{Results}

\subsection{Univariate Analysis}

Appropriate sample descriptive statistics are found in Table 2 of FFS, and discussed on pages 439-440 therein.

\subsection{Multivariate tests}

Table 2 reports the results for the model based on the OLS regression described previously. The results indicate the model has an $F$ - statistic of 182.18 significant at $p<.000$, and generates an adjusted $\mathrm{R}^{2}$ of .80 . In terms of test variables, NATIND is significant at conventional levels with a co-efficient of .171 significant at $p<.02$. This indicates that joint national industry leading city-specific industry leaders who are not overall city leaders generate fee premiums in the order of $19 \%{ }^{8}$ This result reaffirms reported results in FFS. The joint national and city-level industry premiums are not compromised by the exclusion of overall city leadership effects.

Of the remaining test variables, NATOVER, NATALONE, and INDNOTNAT are not significant at conventional levels. However, OVERNOTNAT has a coefficient of

\footnotetext{
${ }^{8}$ The procedure documented in Simon and Francis (1988) calculates the percentage effect of the intercept shift on the dependent variable and is defined as $\mathrm{e}^{\mathrm{z}}-1$, where in this case $\mathrm{z}$ is the parameter value for auditors being joint national industry leading city-specific industry leaders who are not overall city leaders.
} 
.17 and is significant at $p=.078$ two-tailed. Whilst the result is not as strong as that for NATIND, it implies that fee premiums accrue to purely overall city-level leaders, and that these premiums are of a similar magnitude to the joint national and city-specific industry leader premium.

\section{[INSERT TABLE 2 HERE]}

\subsection{Sensitivity tests}

These results are robust to a number of differing model specifications and sensitivity tests utilized in FFS. ${ }^{9}$ For example we rerun the analysis excluding clients in each individual ASX industry, one at a time, with the results being similar to those reported in Table 2. We then eliminate industry codes (21-22) comprising 'miscellaneous industries', and the results are also unchanged. The clients in the two smallest markets Adelaide and Brisbane, are then removed to examine the sensitivity of results to exclusion of the two smallest cities. When this is done, the co-efficient on NATIND is $.224(p=.006)$, and the co-efficient on OVERNOTNAT is .194 ( $p=.067)$. All other test variable co-efficients remain insignificant. ${ }^{10}$ Thus reported results do not appear sensitive to inclusion or exclusion of the two smaller cities. We also run a similar analysis examining the effect of client size on the joint national and city-specific industry

\footnotetext{
${ }^{9}$ Examination of variance inflation factors (VIF's) indicate that most VIF's are less than 2, indicating that consistent with Lardaro (1993), multi-colinearity is not likely to be a concern.

${ }^{10}$ Another sensitivity test involves the removal of the largest audit firm nationally, KPMG. Excluding KPMG makes no difference to the strength of the industry leadership co-efficient.
} 
leadership premium. Consistent with FFS, the size interaction term is positive and significant at $p<.047$.

As a further sensitivity, we look at whether the overall city-specific leadership fee premium extends to an overall national market leadership fee premium effect. Table 1 in FFS indicates the national market leader, KPMG holds 28\% market share, whilst PricewaterhouseCoopers, the second ranked firm nationally holds a $24 \%$ market share. Is there a national market leadership effect or a combined national \#1 and \#2 given these two auditors hold nearly 52\% market share? To test this, we re-run the primary regression model reported in Table 2 including firstly an indicator variable for KPMG, the dominant firm in terms of fees nationally. The result of this additional test indicates no support for the assertion that overall national market leadership fee premiums exist. The coefficient on the joint national and local industry indicator variable NATIND remains at .17, whilst the coefficient on OVERNOTNAT also remains unchanged at .17. In both cases significance levels for these two indicators remain as before. Next we include a dummy for both KPMG and PWC, the national \#1 and \#2. Once again the results are similar, as with further tests documented in footnote $11 .^{11}$ In sum, overall market leadership, measured nationally, does not attract fee premiums whilst locally it does.

\subsection{Re-examination of the Big 5 Premium}

The results in this study pose one last question. Do Big 5 accounting firms that are not joint national and city-specific industry leaders earn a premium over non-Big 5 firms?

\footnotetext{
${ }^{11}$ We also create two additional test variables indicating: a) national market leaders who are not overall local market leaders or national industry \#1 or \#2, and b) national market leading \#1and \#2 who are not overall local market leaders or national industry \#1 or \#2. These additional tests do not alter the results reported in Table 2.
} 
Is it possible that the Big $8 / 6 / 5$ premium identified in prior audit research, and based on firm-wide data, could be confounded by the failure to consider the effects of joint national and city-specific industry leadership? We drop all Big 5 observations coded 1 for NATIND in the sample. The reduced sample is 931 firms comprising 566 Big 5 clients and 365 audited by other auditors. The Big 5 parameter estimate is 0.20 , and the t-statistic of 4.35 is significant at $p<.01$. A parameter value of 0.20 indicates an average Big Five premium of 22\%. We conclude there is a general Big 5 brand name audit fee premium that is separate and distinct from the effects of joint national and city-specific industry leadership by Big 5 audit firms.

\subsection{Summary and conclusions}

The objective of this study was to further the city-level line of inquiry initiated by FSA, and to investigate whether the primary results reported in FFS are sensitive to the differing definitions or characterization of 'leadership' documented in FSA. FFS report that audit industry fee premiums primarily reside with joint national and local office industry leaders. We test whether city-specific market leadership provides a positive signal of audit quality and a basis for charging higher audit fees after controlling for industry leadership effects nationally and at the city-level.

Our results indicate the key auditor characteristic determinant of audit fee premiums appears to be joint national and local industry leadership. This evidence reaffirms that results reported in FFS are robust to inclusion of alternate leadership definitions. In addition, we find evidence of a city-specific overall market leadership premium at a comparable magnitude to city-specific industry leadership, although the 
significance level is somewhat weaker. Together, these two findings highlight the importance of auditor reputation as a city-specific industry leader and overall cityspecific market leader in differentiating amongst auditors in audit markets. Last, we note the Big 5 premium widely documented in the economics of auditing literature does not appear to be a product of joint national and city specific industry leadership effects alone. 


\section{References}

Caminal, R., and X. Vines. 1996. Why market shares matter: an information-based theory. Rand Journal of Economics 27 (Summer): 221-239.

Craswell, A., and J. Francis, 1999. Pricing initial audit engagements: a test of competing theories. The Accounting Review 74: 201-216.

Craswell, A., Francis, J., and S. Taylor. 1995. Auditor brand name reputations and industry specializations. Journal of Accounting and Economics 20: 297-322.

DeFond, M., J. Francis, and T. Wong. 2000. Auditor industry specialization and market segmentation: evidence from Hong Kong. Auditing: A Journal of Practice and Theory 19: 49-66.

Ferguson, A., and D. Stokes. 2002. Brand name audit pricing, industry specialization and leadership premiums post big 8 and big 6 mergers. Contemporary Accounting Research .

Ferguson, A., Francis, J., and D. Stokes. 2003. The Effects of Firm-Wide and Cityspecific Industry Expertise on Audit Pricing. The Accounting Review, 78 (2): 429448.

Francis, J., D. Stokes, and D. Anderson. 1999. City markets as a unit of analysis in audit research and the re-examination of big 6 market shares. Abacus 35: 185-206.

Frank, R., and P. Cook. 1995. The Winner-Take-All Society: Why the Few at the Top Get so Much More than the Rest of Us. The Free Press (New York City, NY).

Hellofs, L., and R. Jacobsen. 1999. Market share and customers' perceptions of quality: When can firms grow their way to higher versus lower quality? Journal of Marketing 63 (January): 16-25.

Kerin, R., P.R. Varadarajan, and R. Peterson. 1992. First-mover advantage: a synthesis, conceptual framework, and research propositions. Journal of Marketing (October): 33-52.

Lardaro, L. 1993. Applied Econometrics. New York: Harper Collins.

Nelson, P. 1970. Information and consumer behavior. Journal of Political Economy 78: 311-329.

Palmrose, Z. 1986. Audit fees and auditor size: further evidence. Journal of Accounting Research 24 (1): 97-110.

Scitovsky, T. 1945. Some consequences of the habit of judging quality by price. The Review of Economic Studies 12: 100-105.

Shapiro, C. 1983a. Optimal pricing of experience goods. Bell Journal of Economics 14: 497-507.

Shapiro, C. 1983b. Premiums for high quality products as returns to reputations. Quarterly Journal of Economics 98: 659-679.

Simon, D., and J. Francis. 1988. The effects of auditor change on audit fees: tests of price cutting and price recovery. The Accounting Review 63: 255-269.

Simunic, D. 1980. The pricing of audit services: Theory and evidence. Journal of Accounting Research 18 (1): 161-190

Smallwood, D., and J. Conlisk. 1979. Product quality in markets where consumers are imperfectly informed. Quarterly Journal of Economics 93: 1-23.

Szymanski, D., S. Bharadway, and P.R. Varadarajan. 1993. An analysis of the market-share profitability relationship. Journal of Marketing 57 (July): 1-18. 
Szymanski, D., L. Troy, and S. Bharadwaj. 1995. Order of entry and business performance: an empirical synthesis and reexamination. Journal of Marketing (October): 17-33.

Wilde, L. 1981. Information costs, duration of search, and turnover: theory and applications. Journal of Political Economy 89: 1121-1141. 
Table 1

Numbers (Percentages) of clients held by each leadership characterization across cities.

\begin{tabular}{lcccccc}
\multicolumn{1}{c}{ City } & Perth & Sydney & Melbourne & Brisbane & Adelaide & Nationally \\
& & & & & & \\
Total Big 5 Sample & $186(27.3 \%)$ & $264(38.8 \%)$ & $137(20.1 \%)$ & $64(9.4 \%)$ & $30(4.4 \%)$ & $681(100 \%)$ \\
\#, \% INDLEAD & $64(34.4 \%)$ & $85(32.2 \%)$ & $44(32.1 \%)$ & $32(50 \%)$ & $22(73.3 \%)$ & $247(36.3 \%)$ \\
\#, \% CITYLEAD & $49(26.3 \%)$ & $52(19.7 \%)$ & $29(21.1 \%)$ & $22(34.4 \%)$ & $9(30 \%)$ & $161(23.6 \%)$ \\
\#, \% COMBLEAD & $35(18.8 \%)$ & $22(8.3 \%)$ & $10(7.3 \%)$ & $13(20.3 \%)$ & $7(23.3 \%)$ & $87(12.8 \%)$ \\
\#COMBLEAD of \#CITYLEAD (\%) & $54.7 \%$ & $25.9 \%$ & $22.7 \%$ & $40.1 \%$ & $31.8 \%$ & $35.2 \%$ \\
Where: & & & & & & \\
INDLEAD = City-specific industry leader & & & & &
\end{tabular}


Table 2

Audit Fee Regression Models (dependent variable is natural log of audit fees)

FFS Combined Model 3

Control Variables:

Intercept

LTA

LSUB

CATA

Quick

DE

ROI

Foreign

Opinion

YE

Loss

\begin{abstract}
Exp.
\end{abstract}
Sign

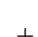

$+$

$+$

$-$

$+$

$-$

$+$

$-$

$\begin{array}{ccc}\text { Estimate } & \text { t-value } & \text { Prob* }^{*} \\ -1.45 & -7.63 & 0.001 \\ 0.46 & 30.84 & 0.001 \\ 0.05 & 9.09 & 0.001 \\ 0.93 & 8.81 & 0.001 \\ -0.03 & -5.12 & 0.001 \\ 0.79 & 4.38 & 0.001 \\ -0.46 & -4.45 & 0.001 \\ 0.69 & 6.6 & 0.001 \\ 0.01 & 0.15 & 0.885 \\ 0.01 & 0.18 & 0.857 \\ 0.01 & 0.02 & 0.984\end{array}$

Experimental Variables:

National \#1 or \#2, and city \#1

National \#1 or \#2, not city \#1

City \#1, not National \#1 or \#2

NATIND

NATOVER

NATALONE

INDNOTNAT

OVERNOTNAT

F-statistic ( $p$-value)

Adjusted $\mathrm{R}^{2}$

Sample Size

*All p-values are two-tail tests
Overall Market Interaction Test

$\begin{array}{ccc}\text { Estimate } & t \text {-value } & \text { Prob* }^{*} \\ -1.54 & -8.02 & 0.001 \\ 0.47 & 31.55 & 0.001 \\ 0.05 & 8.97 & 0.001 \\ 0.93 & 8.71 & 0.001 \\ -0.03 & -4.95 & 0.001 \\ 0.76 & 4.19 & 0.001 \\ -0.46 & -4.46 & 0.001 \\ 0.7 & 6.73 & 0.001 \\ 0.01 & 0.01 & 0.996 \\ 0.02 & 0.35 & 0.725 \\ -0.01 & -0.12 & 0.901\end{array}$

$\begin{array}{lll}0.213 & 3.16 & 0.001 \\ -0.01 & -0.28 & 0.784 \\ -0.08 & -0.96 & 0.338\end{array}$

Control Variables

$\begin{array}{ccc}0.17 & 2.36 & 0.019 \\ -0.05 & -0.34 & 0.732 \\ 0.01 & 0.09 & 0.924 \\ -0.04 & -0.34 & 0.735 \\ 0.17 & 1.76 & 0.078 \\ & 182 & \\ & (<.001) & \\ & 0.8 & \\ & \mathrm{n}=681 & \end{array}$

LTA $=$ natural log of total assets, LSUB $=$ natural log of the number of subsidiaries,

CATA $=$ ratio of current assets to total assets,

Quick = ratio of current assets (less inventories) to current liabilities,

$\mathrm{DE}=$ ratio of long-term debt to total assets,

$\mathrm{ROI}=$ ratio of earnings before interest and tax to total assets,

Foreign $=$ proportion of subsidiaries that represent foreign operations,

Opinion = indicator variable, 1 = qualified audit report,

$\mathrm{YE}=$ indicator variable, 1 = non-June 30th year end,

Loss $=$ indicator variable, $1=$ loss in any of the past three years.

Experimental Variables

NATIND = National \#1 or \#2, city industry \#1 (not overall city \#1)

NATOVER = National \#1 or \#2, overall city \#1 (not city industry \#1)

NATALONE = National \#1 or \#2 alone, (not overall city \#1, or city industry \#1)

INDNOTNAT = City industry \#1 (not overall city \#1) and not national \#1 or \#2

OVERNOTNAT = Overall city \#1 (not city industry \#1) and not national \#1 or \#2 